\title{
Adaptation of social utopia in post-modern society
}

\section{Adaptación de la utopía social en la sociedad posmoderna}

Gleb Dmitrievich Leontyev

Kazan (Volga region) Federal University, Institute of Philosophy, Social Sciences and Mass

Communication, Russia

ORCID: 0000-0001-6568-2485

\section{Ludmila Stanislavovna Leontieva}

Kazan (Volga region) Federal University, Institute of Management, Economics and Finance, Russia

ORCID: 0000-0002-3334-6708

Received 09-08-20 Revised 10-10-20

* Correspondence

Email: gleontyev@me.com
Accepted 20-12-21 On line 03-01-21

Citation:

Gleb Dmitrievich Leontyev, Ludmila Stanislavovna Leontieva (2021). Adaptation of social utopia in post-modern society. Propósitos y Representaciones, 9(SPE2), e1076. http://dx.doi.org/10.20511/pyr2021.v9nSPE2.1076 


\begin{abstract}
System-forming invariants of utopia are analyzed - rationality, criticality, transcendentality, universalism, and projectivity - in the context of post-modern world outlook. The agenda of utopian consciousness is actualized through the statements about the anti-utopian character of postmodernism and the idea of "the end of utopia", concordant with "the end of history". The research objective is to prove the prolongation of utopian discourse after the period of modernism on the basis of systemic approach and philosophical conceptions substantiating the qualitative specificity of the modern society. The analysis is based on the correlation between the presence of specific features of utopian consciousness in the world-outlook picture of the world and the viability of the social utopia phenomenon. Each of the system-forming characteristics of utopia is revealed in the contradictory context of post-modernism. The classical type rationality invariant is manifested through optimization of the social organization pattern, which plays an instrumental role in relation to the moral ideal. In the epoch after modernism, it is "reasonable organization" that represents the utopian ideal. The criticality invariant: on the one hand, post-modernism takes a time-serving position of "linguistic escapism". On the other hand, it criticizes the style of reasoning of the previous epoch. Criticality and pluralism testify to the ability for alternative view at the things existent, the said view being based on the social ideal. The projectivity invariant: on the one hand, post-modernism marks "the end of history" and time. On the other hand, the gnoseological plurality of post-modernism implies individual, polysemantic vision of the objective reality, facilitating the formation of multiple utopian projects, tolerate to simultaneous existence. The transcendentality invariant: on the one hand, post-modernism excluded transcendental narratives from its semantic field. On the other hand, hyperreality with its simulacras generates belief in new metaphysical meanings. The universality invariant: on the one hand, social construction after modernism does not pretend to absolute truth and universal happiness. On the other hand, the global issues actualize the universality approach, while tolerate post-modernism does not deny the co-existence of individualistic utopias and megaprojects common to all mankind. As a result, the authors make a conclusion that the classical utopia crisis has been overcome and there is a trend for further development of utopian discourse due to adaptive transformation of utopian invariants in the society after modernism.
\end{abstract}

Keywords: Invariants of utopia, post-modernism, utopian project, rationality, criticality, transcendentality, universalism, social ideal.

\title{
Resumen
}

Se analizan los invariantes de la utopía que forman el sistema (racionalidad, criticidad, trascendentalidad, universalismo y proyectividad) en el contexto de la perspectiva del mundo posmoderno. La agenda de la conciencia utópica se actualiza a través de los enunciados sobre el carácter antiutopista del posmodernismo y la idea del "fin de la utopía", concordante con "el fin de la historia". El objetivo de la investigación es probar la prolongación del discurso utópico posterior al período del modernismo a partir de un enfoque sistémico y concepciones filosóficas que fundamentan la especificidad cualitativa de la sociedad moderna. El análisis se basa en la correlación entre la presencia de rasgos específicos de la conciencia utópica en la imagen de la perspectiva del mundo del mundo y la viabilidad del fenómeno de la utopía social. Cada una de las características formadoras de sistemas de la utopía se revela en el contexto contradictorio del posmodernismo. El invariante de racionalidad de tipo clásico se manifiesta a través de la optimización del patrón de organización social, que juega un papel instrumental en relación al ideal moral. En la época posterior al modernismo, es la "organización razonable" la que representa el ideal utópico. El invariante de la criticidad: por un lado, el posmodernismo adopta una posición de "escapismo lingǘstico" que sirve al tiempo. Por otro lado, critica el estilo de razonamiento de la época anterior. La crítica y el pluralismo atestiguan la capacidad de una visión alternativa de las cosas existentes, dicha visión se basa en el ideal social. La invariante de la proyectividad: por un lado, el posmodernismo marca "el fin de la historia" y del tiempo. Por otro lado, la pluralidad gnoseológica del posmodernismo implica una visión individual, polisemántica de la realidad objetiva, facilitando la formación de múltiples proyectos utópicos, tolerados a la existencia simultánea. La trascendentalidad invariante: por un lado, el posmodernismo excluyó las narrativas 
trascendentales de su campo semántico. Por otro lado, la hiperrealidad con sus simulacros genera la creencia en nuevos significados metafísicos. La universalidad invariante: por un lado, la construcción social posterior al modernismo no pretende la verdad absoluta y la felicidad universal. Por otro lado, los temas globales actualizan el enfoque de universalidad, mientras que tolerar el posmodernismo no niega la coexistencia de utopías individualistas y megaproyectos comunes a toda la humanidad. Como resultado, los autores llegan a la conclusión de que la crisis de la utopía clásica ha sido superada y existe una tendencia a un mayor desarrollo del discurso utópico debido a la transformación adaptativa de los invariantes utópicos en la sociedad posterior al modernismo.

Palabras clave: Invariantes de la utopía, posmodernismo, proyecto utópico, racionalidad, criticidad, trascendentalidad, universalismo, ideal social.

\section{Introduction}

The philosophic agenda of utopian discourse preserves topicality due to the permanent search for social justice and social ideal. However, the utopian discourse is an ambiguous and contradictory process. History testifies to the dangers of ideological transformation of social utopia and inadequate implementation of social ideals (Leontyev et al., 2018). As a consequence, social consciousness becomes disappointed with the ideas of progressism and social goal-setting, producing ideas like F. Fukuyama's "the end of history" and F. Nietzsche's "Gott ist tot". As an American philosopher F. Jameson wrote, "the young generation of the 1960-s transferred to confrontation with former oppositionists among modernists, considering them to be 'dead classics" (Jameson, 1984). In the context of deepening gnoseologic pluralism and socialtechnological innovations of the post-industrial society, speculations of fundamental anti-utopian character of post-modernism world outlook are formed (Leontyev, 2017) and the statement by H. Marcuse about "the end of utopia" gains popularity. Declaring "the end" of the classical utopia of social abundance due to its "fundamental accessibility", H. Marcuse does not consider "utopian the very idea of drastic transformation", as this idea is based on "the vital need for freedom" (Marcuse, 2004). Stemming from that, "the end of utopia" should be understood as a metaphor determined by the gnoseological situation of the classical utopia crisis. But crisis as a moment of sudden change, overcoming and transition to a new quality stimulates adaptive abilities and creative potential of the utopia phenomenon. Viability and integrity of the utopia is determined by specific characteristics, utopian constants. Analysis of research literature allowed identifying the following invariant features of utopia (Leontyev, 2017): rationality, criticality, projectivity, transcendentality, and universalism. In our opinion, these constants preserve their functional capability both in the context of industrial and post-industrial, informational society. Prolongation of the functioning of these characteristics under the new social-gnoseological conditions proves that the crisis of the utopia in the world outlook picture of the world after modernism does not imply the cessation of utopian discourse. The arguments to substantiate this statement are given in the process of utopia invariants analysis under post-modernism.

\section{Bibliographic Review}

The research is based on the works by F. Ainsa (1999), E. Bloch (Bloch, 2000), J. Maravall, H. Marcuse and others, devoted to social utopia as "the principle of hope", universal property of existence, specific type of consciousness, artistic genre, possessing a set of constant features (Ainsa, 1999).

\section{Methods}

The methodological basis of the research are the conceptions which substantiate the qualitative specificity of the modern society as a post-industrial one (Bell, 1973; Masuda, 1983, Fukuyama, 2002 and others), characterizing the informational world-outlook situation in the aspects of producing virtual reality (Baudrillard, 1981), "the end of utopia" (Marcuse, 2004) and "cultural 
domination" of transnational capitalism, i.e. post-modernism (Jameson, 1984) with actual trends of transition to discursive practices of meta-modernism (T. Vermeulen, R. van den Akker (Vermeulen \& van den Akker, 2010; Nealon, 2012; Eshelman, 2008). From the viewpoint of systemic approach, utopia is researched in post-modernism context as a social-communicative formation with invariant characteristics.

\section{Results And Discussion}

Social utopia is an integral, social-regulative, communicative formation, the utopian discourse is a reflexive process of discussing and asserting the value foundations of the socially-ideal. As a communicative phenomenon, utopia is intertwined with the social context. Dissatisfaction with the present existence generates critical reasoning over reality, while its analysis produces questions related to the structure of a better world order. From the viewpoint of systemic approach, the integrity of a complex social object is demonstrated through its constant characteristics. Thus, to prove the prolongation of the utopian discourse, we analyze the presence of system-forming invariants of utopia in the post-modernism discourse. Ambiguity of the term 'post-modernism' was shown in classification by Nik F. Fox, who distinguished between two types of postmodernists (Fox, 2003). The first type is "affirmative" post-modernists - their world outlook present re-thinking of the modernist epoch, which historically comprises the Modern Era. The second type is "skeptical" post-modernists, disclaiming that very modernism. Our objective is to correlate the utopian invariants with the world-outlook specificity of post-modernistic denial and re-thinking.

Rationalism. The hypothetical constructs of an ideal state were generated by reason. The universal paradigm of rationality, object-centered, is characteristic for the modernist epoch. It is a classical type of rationality, operating with the notion of an abstract human being. The abstract nature of the subject leads to schematization of the optimally organized utopian future. Within the post-nonclassical paradigm, one may speak of the inclusion of axiological parameters of human existence into the process of cognition. The mutual correlation of knowledge, ideas and value orientations allows asserting the fact that, while social utopia played a secondary, instrumental role in relation to the moral ideal in classical utopia, in the post-modern epoch it is the "reasonable organization" (L. Sargent) that presents the utopian ideal. Discrediting the cult of Reason, postmodernism does not deny rationalism as a philosophical-world-outlook attitude, but asserts the change of rationality types: from the classical type to nonclassical and post-nonclassical. The significance of instrumental rationality in the fundamental values of a post-modern society decreases. This trend was marked in the concept of post-material values by R. Inglehart, and is manifested in the shift from materialistic priorities of survival to the priorities of "maximizing subjective well-being", quality of life and "the growing concern for highest goals" (Inglehart, 1997). Social utopia as an act of creativity is indispensable from the personality of its creator. If such author ignores the value structure of the contemporary society and proposed future, this may nullify the very idea of social-utopian modeling. Within the post-nonclassical paradigm, the utopia author's personality is not opposed to the society as an object of comprehension, and recognition of the significance of the subjective differences of the "utopia authors" determines the pluralism of social-political construction. Thus, correlation of social ideas with value orientations of activity makes it possible to assume that the post-nonclassical paradigm of rationality does not exclude utopian consciousness but, moreover, creates conditions for utopia diversification.

Criticality. Utopian ideal of the future society is often constructed as the antithesis to the existing one, i.e. on the basis of critical comprehension of the reality and reverse projection of the image to the utopian space. Critique implies contradictions discovered by a thinking subject. As the world is conceived by post-modernism as a text, critique of the reality is performed in interpretation of texts, in search of semantic contradictions of language codes. It is a creative act of resistance to the normative-regulative principles of "episteme", which, according to M. Foucault, set the direction of thought-action, at that legitimizing power. As a result, first, post-modernism distances goes from the contradictions of objective reality to discursive practices, taking the timeserving position of linguistic escapism. Second, the artistic-imaginative critique of postmodernistic world outlook is aimed at the reasoning style of the previous epoch through original 
deconstruction. If critical thinking is interpreted as "dissension", then plurality of post-modernism demonstrates the apogee of this ability. At the same time, any form of critique implies a mental image of the consistent desired, the ideal. Consequently, the existence of utopia with its critical pathos is continued in the new social-worldoutlook context.

Projectivity. A project is representation of the reality, an image which can be exposed to subjective impact, as it contains the potential of overcoming the contradiction between the author's needs and the world. Utopia sets an ideal image embodied in a project. But the project of the future is not a prognosis. The project of a prognosis is based on empirical experience and logic of causeand-effect determination of social processes' development. A project of the future utopia is formed on the basis of comprehending practice through the ideal of a better world order, i.e., in the logic of maximally possible correlation between an object and its idea. In both cases, the property of objectivity is understood as a transforming thought-action oriented to the future. In the temporal aspect, post-modernism is a period at the "end of history", "after the orgy" (Baudrillard, 1981), when everything has occurred and there is no need in rational construction of the future. However, gnoseological pluralism corrects the linear dependence. Reality in post-modernism is "a set of chaotically occurring and arbitrarily interpreted symbols" (Inglehart, 1997). On the one hand, the chaotic character of the reality minimizes the probability for social foresight. On the other hand, polysemantic vision of this reality is assumed. It means that as a result of special interpretation of a set of symbols, multiple utopias may be formed, which would be tolerant to simultaneous coexistence. Moreover, reality without universal theoretical schemes and ideologemes, without preset meanings is an actual object of research for social-project thinking. As a result, one may foresee the growing scale of social-project activity under post-modernism. The phenomenon of projectivity broadens the sphere of its application: from nature and society it shifts towards socialpsychological, mental spheres. The evidence of orientation towards correcting the very nature of humans, the trend to managing thinking is, for example, eupsychias of the post-nonclassical utopian discourse.

Transcendentality. Beyond sensual experience, on the other side of things existent, there is transcendence, for example, the concept of God. But post-modernism has "discarded the religious metanarrative from its semantic field, together with all other transcendent narratives and mythology" (http://metamodernizm.ru). In the context of subjective empirics, there is no metaphysical, and without limits there is nothing beyond the limits. Hence, it is the world of total immanence. Nevertheless, the conceptual system of J. Baudrillard, which describes the situation of post-modernism, is transcendent. His hyperreality with the world of simulacra and metaempirics is comparable to the apriority of the transcendent. Moreover, by J. Baudrillard's classification, simulacra of the first order correspond to "the imaginative of the utopia". The distance between the real and the imaginative, according to the philosopher, "is maximized in the utopian, in which the sphere of the transcendent, the cardinally different world, emerges" (Baudrillard, 1981). This different world is described by the philosopher in his book "Simulacra and simulations" as a romantic dream, "in which transcendence is thoroughly drawn" and "the island of utopia opposes the continent of the real". It means that neither the transcendental, nor the utopian are alien to the post-modernistic hyperreallity. The idea of saving the world through the transcendent world runs through the human history parallel to various stages of utopian discourse. Besides, the new, incipient disposition is aimed against discrediting the "transcendence" notion. According to $\mathrm{T}$. Vermeulen and R. van den Akker: "We will call this discourse, oscillating between a modern enthusiasm and a postmodern irony, metamodernism" (Vermeulen \& van den Akker, 2010). Metamodernism combines "the naïve belief in the future formation of new metaphoric meanings of existence and acceptance of the 'depth' and 'large scale' of spaces" (http://metamodernizm.ru). That is why artists-metamodernists "look back to perceive anew a future that was lost from sight" (Vermeulen \& van den Akker, 2010). Stemming from the emergent paradigm of forming the new meanings of the social existence "within the limits of the limitless" future, we make a conclusion on rehabilitation of the transcendent. It means that metamodernistic utopias of the future will not be limited to the indicators of practical efficiency and the highest rationale will return to them. 
Universalism. Universalism as a multi-aspect idea of the common good forms the methodological basis for utopian approach: in theological aspect, as conviction in the possibility to save the humankind; in ethical aspect, as the idea of the categorical imperative formula; in philosophical sense, as the paradigm of knowledge, based on the principles of unity, commonality and integrity. However, the universalist collective good, determined by the logic of cause-andeffect regularities, is perceived by the pluralistic post-modernism as dogmatism. Distrust towards "great megtanarratives" determines the formation of utopian discourses in separate fragments of the society. These utopian ideas have no centripetal aspirations to unite and do not claim for absolute truth. However, in the context of aggravating global problem, under the global crisis, for example, in the actual situation of struggling against the COVID-19 pandemics, it is the universalism and humanism that become the salutary principles of the world outlook. As early as in the middle of the past century, a German futurologist O. Flechtheim (Flechtheim, 1966), identifying the alternative variants of the future, alongside with the catastrophic prognoses of the humanity perishing in a nuclear disaster or establishing a neo-Caesarian civilization, suggested the opportunity for optimistic overcoming of threats - the humanity uniting into a global federation built on truly humanistic principles. The success of the global unification utopias is based on the principle of tolerance, first, as a characteristic of universalism, second, as a feature of postmodernism. Stemming from that, in the poly-utopian discourse of the modern era, humanistic universality megaprojects are inevitable on terms of peaceful coexistence.

\section{Summary}

The work reveals the adaptive potential of the utopian invariants (rationality, criticality, projectivity, transcendentality, and universality) in the world-outlook paradigm of the post-modern epoch. Today, the utopian consciousness is formed in the context of socio-cultural pluralism and relativism, when, on the one hand, any concept has a right to existence, and on the other hand, it may be re-thought and exterminated. This is also true for post-modernism per se. Concerning its further viability, the opposite views are highlighted: 1) post-modernism finished its existence at the verge of the centuries (Eshelman, 2008); 2) post-modernism possesses the characteristics of a "ghost" as pointed out by J. Derrida, i.e. is not present and is not absent; 3) post-modernism is intensified and transformed into post-post-modernism (Nealon, 2012). Regardless of the hypostasis of its existence, post-modernism does not exclude utopia from the world-outlook discourse, but creates conditions for its transformation in compliance with the changed paradigm of scientific cognition and social practice.

\section{Conclusions}

Based on the preserved viability of utopian invariants in the world-outlook system of the modern society, one may state the polyvariety of the forms of the classical utopia transformation. Spheres of its existence vary, as well as the globality-localilty of its scale and its organizational content. Practopias of a wide social range and polyutopias of the ideal world are formed, in which various utopian formations harmoniously coexist: from individualistic, psychological, to universal, common to all mankind.

Stemming from the above, the crisis of the post-industrial society ideals is not as much "the end of utopia", as the Renaissance of utopia, based on re-thinking of its metaphysical foundations after the epoch of modern.

\section{References}

Ainsa, F. (1999). La Reconstruccion de la Utopia. Mexico. Correo de la UNESCO. - 238 pp.

Baudrillard, J. (1981). Simulacres et simulation, Paris: Galilée, 240 pp.

Bell, D. (1973). The coming of post-industrial society: A venture in social forecasting. Daniel Bell. - New York: Basic books, - 507 pp.

Bloch, E. (2000). The spirit of Utopia. Standford: Stanford University Press, - 320 p. - URL: https://kupdf.com/download/bloch-ernst-spirit-utopia_58d15501dc0d60c608c34614_pdf

Dempsey, B. [R]econstruction: Metamodern 'Transcendence' and the Return of Myth.- URL: http://metamodernizm.ru/reconstruction/ 
Eshelman, R. (2008). Performatism, or the End of Postmodernism. Aurora: Davies Group, 270 pp. Flechtheim, O.K. (1966). History and futurology. Foreword by Robert Jungk. Meisenheim am Glan: Anton Hain Verlag, 126 pp.

Fox, N.F. (2003). The new Sartre: Explorations in Postmodernism. N.Y., L., 208 pp.

Fukuyama, F. (2002). Our Posthuman Future: Consequences of the Biotechnology Revolution. New York: Farrar, Straus, and Giroux, $-256 \mathrm{pp}$.

Inglehart, R. (1997). Post-modernism: changing values and changing societies. Polis. Political studies, 4, 6-32.

Jameson, F. (1984). Postmodernism, or the Cultural Logic of Late Capitalism. New Left Review, 146, 53-92.

Leontyev, G. D. (2017). Anti-Utopia of the Postmodernism or Postmodernism of the Utopian? / G. D. Leontyev. UrFU Newsletter. Series № 3. Social sciences, 12, 2 (164), 78-86.

Leontyev, G. D., Leontieva, L. S., \& Khalilova, T. V. (2018). Implementation of state Utopia: issues of property and freedom. 5th International Multidisciplinary Scientific Conference on Social Sciences and Arts SGEM 2018, www.sgemsocial.org, SGEM2018 Conference Proceedings, ISBN 978-619-7408-64-5 / ISSN 2367-5659, 26 August - 1 September, 5(1), 383-389.

Marcuse, H. (2004). End of utopia. Logos, 6(45), 18-23.

Masuda, Y. (1983). The Information Society as Postindustrial Society. Wash.: World Future Soc.,. $-419 \mathrm{pp}$.

Nealon, J.T. (2012). Post-postmodernism; or, The Logic of Just-in-Time Capitalism. Stanford: Stanford University Press, $248 \mathrm{pp}$.

Vermeulen, T., \& van den Akker, R. (2010). Notes on metamodernism. Journal of Aesthetics and Culture, 2. DOI: 10.3402/jac.v2i0.5677 